\title{
Antifouling and antibacterial activities of bioactive extracts from different organs of the sea cucumber Holothuria leucospilota
}

\author{
Mehrnoosh Darya ${ }^{1}$, Mir Masoud Sajjadi ${ }^{*}$ (D), Morteza Yousefzadi ${ }^{2}$, Iman Sourinejad ${ }^{3}$ and Maaroof Zarei ${ }^{4}$
}

\begin{abstract}
In this study, antifouling and antibacterial properties of polar, semi polar and non-polar bioactive compounds derived from the sea cucumber Holothuria leucospilota were investigated. A series comprising $n$-hexane, ethyl acetate and methanol extracts from four different organs of sea cucumber (body wall, gonad, digestive tract and respiratory tree) were investigated for their antibacterial and antifouling activity against two species of microalgae, larvae of barnacle Amphibalanus amphitrite and a non-target organism: larvae of Artemia salina. Results showed that the highest antibacterial activity was found in the ethyl acetate extract of body wall against Staphylococcus aureus with minimum inhibitory concentration (MIC) of $0.250 \mathrm{mg} / \mathrm{mL}$. The MIC of ethyl acetate extract of body wall ranged between 0.062 and $0.250 \mathrm{mg} / \mathrm{mL}$ against two microalgal strains. All extracts showed moderate to low toxicity against larvae of barnacles. The most pronounced anti-barnacle activity was found in the ethyl acetate extract of body wall with median lethal concentration $\left(\mathrm{LC}_{50}\right)$ value of $0.049 \mathrm{mg} / \mathrm{mL}$. Among the twelve extracts, the ethyl acetate extracts of body wall showed the maximum antibacterial and antifouling activities. The bioactive compounds of the ethyl acetate extract of the sea cucumber body wall were determined using gas chromatography coupled with mass spectrometry. Fatty acids and terpenes were the major compounds, which may be responsible for antibacterial and antifouling activity of the ethyl acetate extract of body wall of the sea cucumber $\mathrm{H}$. leucospilota.
\end{abstract}

Keywords: Secondary metabolites, Biofouling, Barnacle, Microalgae, Antifouling, GC-MS

\section{Background}

Marine biofouling refers to the gathering of unwanted microorganisms, algae, and animals on an artificial surface immersed in the seawater [1-3]. Marine organisms which cause the fouling are various and include many species from protozoa to vertebrates [3-5]. However, bacteria, diatoms, barnacles and macroalgae are some of the most important marine fouling organisms. Marine biofouling is a serious worldwide problem affecting marine industries and any man-made structure exposed to marine environments [6] such as ships, pipelines, oil

*Correspondence: mmsajjadi@hotmail.com

${ }^{1}$ Department of Fisheries, Faculty of Natural Resources, University of Guilan, Sowmeh Sara, Iran

Full list of author information is available at the end of the article platforms, fish cages and fishing nets [7, 8]. Biofouling can reduce the speed of vessels and increase fuel consumption. It also increases emissions of greenhouse gases [9-12]. It has been reported that biofouling can cause huge economic losses of more than US\$ 5.7 billion per year over the world $[6,13]$.

In order to overcome the biofouling problems, antifouling paints for marine structures have been developed. Antifouling paints based on tributyltin and other organotin compounds as the active agents pose a serious threat to the marine environment [14]. Tributyltin has been found to be harmful and toxic to non-target organisms and is not easily degraded in the environment [1]. Consequently, because of the above-mentioned problems, International Maritime Organization banned the use of tributyltin since September 2008 [1, 15]. Since the 
banning of tributyltin and other tin-based compounds, the tin is replaced by other metals like zinc [16], titanium and mostly copper $[17,18]$. Copper has good antifouling properties against some of the biofouling organisms like algae and barnacles [19], but copper can concentrate in shellfish tissues and has negative impacts on developing vertebrates and invertebrates $[11,20]$. Therefore, there is a need for new environment-friendly antifoulants [21, 22].

Natural products from marine organisms are among the most promising antifouling compounds [23, 24]. Marine invertebrates are potential sources of bioactive natural products which are used against predators and external threats like biofouling species [25, 26]. Sea cucumbers are marine invertebrates belonging to the phylum Echinodermata, class Holothuroidea [27]. There are over 1716 species of holothurians all over the world with the greatest number being in the Asia Pacific region [28]. Sea cucumbers are found on the sea floor and secrete secondary metabolites like triterpene glycosides from their skins, body walls, gonads, viscera and cuvierian tubules to protect themselves from predators [29, 30]. A large number of secondary metabolites and compounds has been isolated from sea cucumbers [27, 31]. These compounds possess biological activities such as anti-microbial, anti-oxidant, anti-angiogenic, anti-viral, anti-tumoral and other specific properties [32-35].

Different biological activities of extracted secondary metabolites from sea cucumbers have been explored in previous studies but their antifouling properties have been less investigated. Mert Ozupek and Cavas [30] reported antifouling properties of triterpene glycosides derived from Holothuria tubulosa and Holothuria polii. Soliman et al. [7] showed antibacterial and antifouling properties of Red Sea cucumbers. Genus Holothuria is the most harvestable genus of sea cucumbers [27]. Holothuria leucospilota is a black/red, cylindrical and elongate sea cucumber with a soft and pliable body covered with soft papillae. This species is usually found in coral reefs' sandy area and coastal rocky shores and is supposed to be the dominant species in the Persian Gulf [36]. The present study aimed at evaluating the antibacterial and antifouling properties of bioactive compounds from four organs (body wall, gonad, digestive tract and respiratory tree) of the sea cucumber H. leucospilota from Hengam Island, the Persian Gulf, Iran.

\section{Materials and methods}

\section{Sample collection and extracts preparation}

The sea cucumber $H$. leucospilota specimens were hand collected by scuba diving from Hengam Island, the Persian Gulf, Iran. Sea cucumbers were anaesthetized in a $5 \%$ solution of $\mathrm{MgCl}_{2}$ in distilled water before being dissected. Then, they were washed by fresh water and each sea cucumber was cut from the anus to the mouth [37]. The sections of the body wall, gonad, digestive tract and respiratory organ were cut into small pieces and freeze-dried, separately. The dried sea cucumbers were powdered using a blender before extraction. About $100 \mathrm{~g}$ of each section was extracted separately with three types of solvent based on polarity including $n$-hexane (nonpolar), ethyl acetate (semi polar) and methanol (polar), respectively at $23{ }^{\circ} \mathrm{C}$ for 2 days in the dark. The solvents were used in series from low to high polarity to realize the exact components extracted with each polarity and so, the influence of solvents with different polarities on the extraction of components was determined. The extracts were filtered and concentrated under reduced pressure to remove the solvent. The dried extracts were kept in dark at $4{ }^{\circ} \mathrm{C}$ until later testing.

\section{Antibacterial assay \\ Bacterial strains}

Two Gram-positive (Staphylococcus aureus and Micrococcus luteus) and three Gram-negative bacterial strains (Escherichia coli, Klebsiella pneumoniae, and Vibrio harveyi) were used in the antibacterial assay. All the bacterial strains were obtained from the Pasteur Institute, Tehran, Iran.

\section{Antibacterial screening}

Antibacterial activity of the $\mathrm{H}$. leucospilota extracts was assessed by disk-diffusion method. An overnight culture of each bacterial species was prepared and adjusted according to the $0.5 \mathrm{McF}$ arland standard $\left(1.0 \times 10^{8} \mathrm{CFU} /\right.$ $\mathrm{mL}$ ). An amount of $100 \mu \mathrm{L}$ of a suspension of each bacterium was spread over Mueller-Hinton Agar plates. Whatman paper disks of $6.4 \mathrm{~mm}$ diameter were impregnated with $10 \mu \mathrm{L}$ of each extract (concentration of $10 \mathrm{mg} / \mathrm{mL}$, final doses per disk: $0.1 \mathrm{mg}$ of each extract) and placed on the agar surface. Disks impregnated with DMSO (solvent) and standard antibacterial agent ampicillin (at $10 \mu \mathrm{g} /$ disc), were used as positive control and control (respectively). The plates were incubated at $37^{\circ} \mathrm{C}$ for $24 \mathrm{~h}$. Antibacterial activity was evaluated by measuring the diameter of the inhibition zone (IZ) of growth, formed around the paper disk. All assays were repeated three times.

\section{Determining minimum inhibitory concentration (MIC) for bacteria}

MIC values were determined using the Broth dilution method [38]. The serial dilutions of sea cucumber extracts from 2.00 to $0.062 \mathrm{mg} / \mathrm{mL}$ in Mueller-Hinton Broth containing $0.5 \%$ Tween 80 for all bacterial strains were applied. A concentration of $10^{5} \mathrm{CFU} / \mathrm{mL}$ was used 
for test bacteria culture. The solvent DMSO and tube without any extract were used as controls. The lowest concentration of each extract with no bacterial growth after $24 \mathrm{~h}$ of incubation at $37^{\circ} \mathrm{C}$, was noted as MIC. All the experiments and controls were performed with three replicates.

\section{Antialgal assay \\ Microalgae preparation}

The sea cucumber extracts were tested for antialgal activity against two species of microalgae: Chaetoceros muelleri and Chlorella vulgaris, obtained from the Persian Gulf and Oman Sea Ecological Research Institute, Bandar Abbas, Iran. Marine microalgae were grown under controlled conditions at $25^{\circ} \mathrm{C}$ with a $12: 12$ light-dark cycle in $\mathrm{F} / 2$ medium [39].

\section{Determination of MIC for microalgae}

Like the antibacterial assay, the MIC against two marine microalgae was determined with six different concentrations of sea cucumber extracts using a test tube. Initial cell density was $1.0 \times 10^{5}$ cells $/ \mathrm{mL}$. Prior to the experiments, all of the dried sea cucumber extracts were dissolved in DMSO and pipetted into the test tubes. The concentrations were obtained by serial dilution. Then, the tubes were incubated under a controlled condition at $25^{\circ} \mathrm{C}$ with the illumination of $4000-5000 \mathrm{~lx}$ light intensity [6] with a 12:12 h light/dark cycle. Untreated tube and those containing DMSO served as controls. The assay was conducted with six replicates. The minimum concentration of each extract, where no microalgal growth was observed in at least four of the six tubes, was recorded as the MIC [6].

\section{Barnacle cytotoxicity assay}

Adults of the striped acorn barnacle, Amphibalanus amphitrite were collected together with their rock substratum from intertidal rocks in Bandar Abbas, southern Iran. To obtain larvae, broods were left to dry overnight, and upon immersion in filtered seawater (salinity $35 \%$ and temperature $25{ }^{\circ} \mathrm{C}$ ) [40], the broods released nauplius larvae [41]. Test samples (all 12 dried extracts) were dissolved in DMSO. Six different concentrations were prepared based on serial dilution method. The solution of each concentration was pipetted into 24-well polystyrene plates, and filtered seawater containing 10-20 larvae was added. The plates were kept in dark at $25{ }^{\circ} \mathrm{C}$ [42]. The numbers of larvae that remained alive and died were counted after $24 \mathrm{~h}$. The barnacles that did not move and did not respond to light or touch by a metal probe were regarded as dead [40], and the toxicity, which was expressed as the $\mathrm{LC}_{50}$ value was calculated based on Probit analysis with
$95 \%$ of confidence interval. The same assay without any extract added to the wells and another with DMSO was done as control. All the experiments and controls were performed with three replicates.

\section{Brine shrimp cytotoxicity assay}

Brine shrimp Artemia salina cysts were hatched in a flask containing filtered seawater, with continuous light $\left(3500 \pm 500\right.$ Lux) and aeration at $28-30{ }^{\circ} \mathrm{C}$. The nauplii were hatched within $48 \mathrm{~h}$. The extracts were dissolved in DMSO and six different concentrations were prepared by serial dilution. The cytotoxicity assay was assessed using 24 -well plates. A volume of $200 \mu \mathrm{L}$ of each extract solution, $1.80 \mathrm{~mL}$ aerated seawater and $10-20$ nauplii were added into each well of a 24-well plate [43]. Wells containing sea water and solution of DMSO in sea water were considered as controls. There were three replicates for each concentration and control. A checking count was performed, and the numbers of dead nauplii were counted after $24 \mathrm{~h}$ incubation. The percentage of mortality was determined and $\mathrm{LC}_{50}$ value was calculated using Probit analysis with $95 \%$ of confidence interval [44].

\section{Gas Chromatography/mass spectrometry (GC-MS) analysis}

Based on the highest inhibitory activity, the ethyl acetate extract of body wall was chosen for further experiments. In order to identify the bioactive compounds of semi-polar (ethyl acetate) extract from Holothouria leucospilota, gas chromatography/mass spectrometry was performed.

The ethyl acetate extract from body wall of $H$. leucospilota were analyzed by GC-MS using an Agilent GC 7890B and Mass 5977A with HP-5MS ultera inert column $(30 \mathrm{~m} \times 0.25 \mathrm{~mm} \times 0.25 \mu \mathrm{m})$. Helium carrier gas was used at a constant flow rate of $1 \mathrm{~mL} / \mathrm{min}$. The ion source and injector temperature were 230 and $260{ }^{\circ} \mathrm{C}$, respectively. A splitless mode with $1 \mu \mathrm{L}$ injection volume and the flow rate of $1 \mathrm{~mL} / \mathrm{min}$ was applied. The NIST GC-MS library was used to identify compounds and the closest match was recorded.

\section{Statistical analysis}

Differences in antibacterial activity (inhibition zone) between extracts and the control for each bacterial strain were analyzed by one-way analysis of variance (ANOVA) followed by tukey's multiple comparison test. Significance was evaluated at the $5 \%$ level $(P<0.05)$. The concentration of the extracts that resulted in $50 \%$ mortality $\left(\mathrm{LC}_{50}\right)$, were calculated using the Probit software program. 


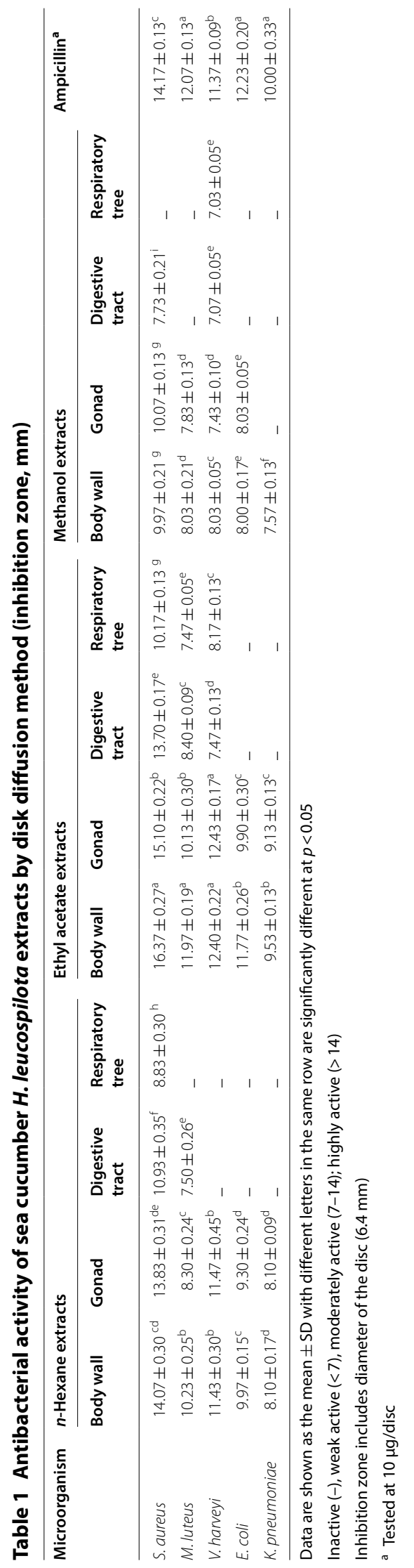




\section{Results}

Antibacterial assay

The results of evaluating the antibacterial activity of the sea cucumber extracts from $H$. leucospilota using disk diffusion method and MIC are shown in Tables 1 and 2. Based on the scaling method that [45] suggested to explain microbial activity, among the twelve $H$. leucospilota extracts, $n$-hexane extract of the body wall and ethyl acetate extracts of the body wall and gonad exhibited strong antibacterial activity against Grampositive bacterium $S$. aureus and moderate activity against other Gram-positive and Gram-negative test bacteria.

Among the bacterial strains tested, K. pneumoniae with $\mathrm{MIC} \geq 2 \mathrm{mg} / \mathrm{mL}$ and the minimum number of extracts that affected it, was the most resistant bacterium. Among the twelve $H$. leucospilota extracts, only ethyl acetate extracts of the body wall and gonad inhibited the growth of all tested bacterial strains (by disc diffusion method) and showed a MIC $\leq 2 \mathrm{mg} / \mathrm{mL}$ at the same time.

\section{Antialgal assay}

The antimicroalgal activity of the twelve extracts of $H$. leucospilota against the two species of microalgae, Chaetoceros muelleri and Chlorella vulgaris are shown in Table 3. The ethyl acetate extract of the body wall showed strong inhibition with the MIC of $0.062 \mathrm{mg} /$ $\mathrm{mL}$ against $C$. muelleri. The lowest inhibitions were observed in $n$-hexane extracts. $n$-Hexane extract of respiratory tree showed no inhibition effect against $C$. vulgaris.

\section{Anti-barnacle assay}

As shown in Table 4, the four ethyl acetate extracts showed moderate toxicity against $A$. amphitrite larvae, with $\mathrm{LC}_{50}$ values all below 0.1 and above $0.048 \mathrm{mg} /$ $\mathrm{mL}$. The most pronounced cytotoxic activity against A. amphitrite was found in ethyl acetate extract of the body wall, which had the $\mathrm{LC}_{50}$ of $0.049 \mathrm{mg} / \mathrm{mL}$ followed by methanol extract of the body wall with $\mathrm{LC}_{50}$ of $0.055 \mathrm{mg} / \mathrm{mL}$. Among the twelve extracts tested, $n$-hexane extract of the respiratory tree showed the lowest cytotoxic activity against barnacle larvae, with an $\mathrm{LC}_{50}$ of $0.284 \mathrm{mg} / \mathrm{mL}$.

\section{Cytotoxicity against artemia}

The mortality rate of barnacle and artemia for the extracts are shown in Fig. 1. All tested extracts had higher toxicity activity with higher mortality against barnacle than artemia. As presented in Table 5, among the twelve extracts tested, ten extracts had an $\mathrm{LC}_{50}$ above $0.1 \mathrm{mg} / \mathrm{mL}$ against $A$. salina. This indicates that toxicity to this non-target organism is very low. Two other extracts, ethyl acetate and methanol extract of body wall showed moderate toxicity to A. salina, with $\mathrm{LC}_{50}$ values of 0.088 and $0.095 \mathrm{mg} / \mathrm{mL}$, respectively.

\section{Gas chromatography/mass spectrometry}

Based on the results from GC-MS, the ethyl acetate extract from body wall contained two major categories of compounds, terpene and terpenoids and fatty acids (Table 6). Among terpenes, (3 $\beta$ )-olean-12-ene-3,28-diol showed the highest area (14.116\%) followed by 1,1-bis(5methyl-2-furyl)cyclohexane, (8.225\%). Among the fatty acids, oleic acid showed the highest area (4.753\%) followed by cis-13-eicosenoic acid (4.281\%).

\section{Discussion}

The extensive use of toxic and harmful biocides in antifouling paints has increased concerns about their adverse effects on the marine environment. Consequently, conducting research for identifying potential environmentfriendly antifouling agents has been a challenge and of huge interest for scientific communities. Marine natural products are among the most promising alternatives to the toxic and harmful antifouling biocides. Secondary metabolites from marine invertebrates display a wide range of bioactivities, for example, antibacterial, antifungal and cytotoxic effects. The present research focused on the antibacterial and antifouling activity of polar, semi polar and non-polar extracts from the sea cucumber $H$. leucospilota.

Antibacterial activity was detected in several extracts from different sections of the body using different solvents, but mainly in ethyl acetate extracts obtained from body wall and gonad. Among the tested extracts, ethyl acetate extract obtained from the body wall showed higher antibacterial activity against $S$. aureus with the inhibition zone of $16.37 \pm 0.27 \mathrm{~mm}$ and MIC of $0.25 \mathrm{mg} /$ $\mathrm{mL}$. The methanol extracts showed the lowest activity against all tested bacteria compared to other extracts. The methanol extract obtained from the body wall showed a low activity against $S$. aureus and $E$. coli with MIC of $1 \mathrm{mg} / \mathrm{mL}$ and $2 \mathrm{mg} / \mathrm{mL}$. These findings were in line with Farjami et al. [46] who reported that chloroform and hexane extracts of different body parts of $H$. leucospilota had more antibacterial activity than methanol extract.

With regard to this point that different solvents with different polarities were used for the extraction of natural compounds from the sea cucumber, therefore the observed antibacterial, anti-microalgal and cytotoxic activities may be attributed to the different bioactive compounds extracted from $H$. leucospilota. The majority of the positive results in the present study were recorded 


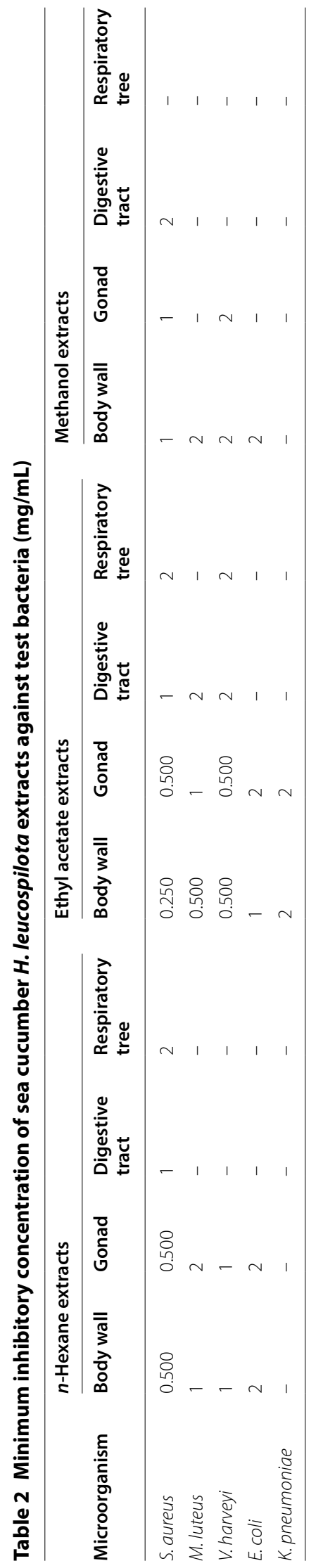




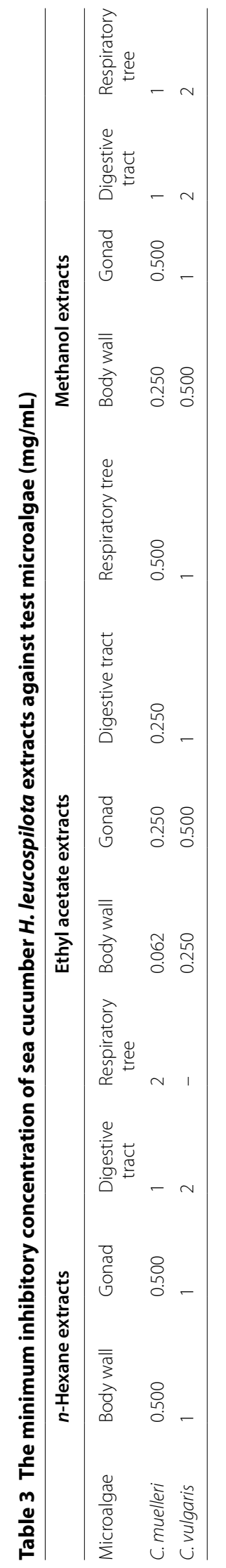




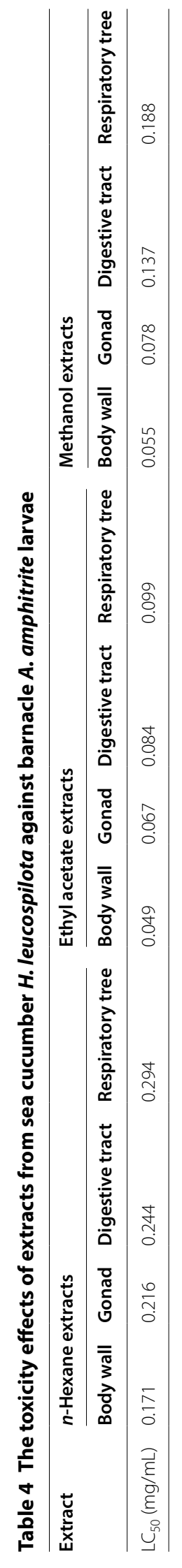




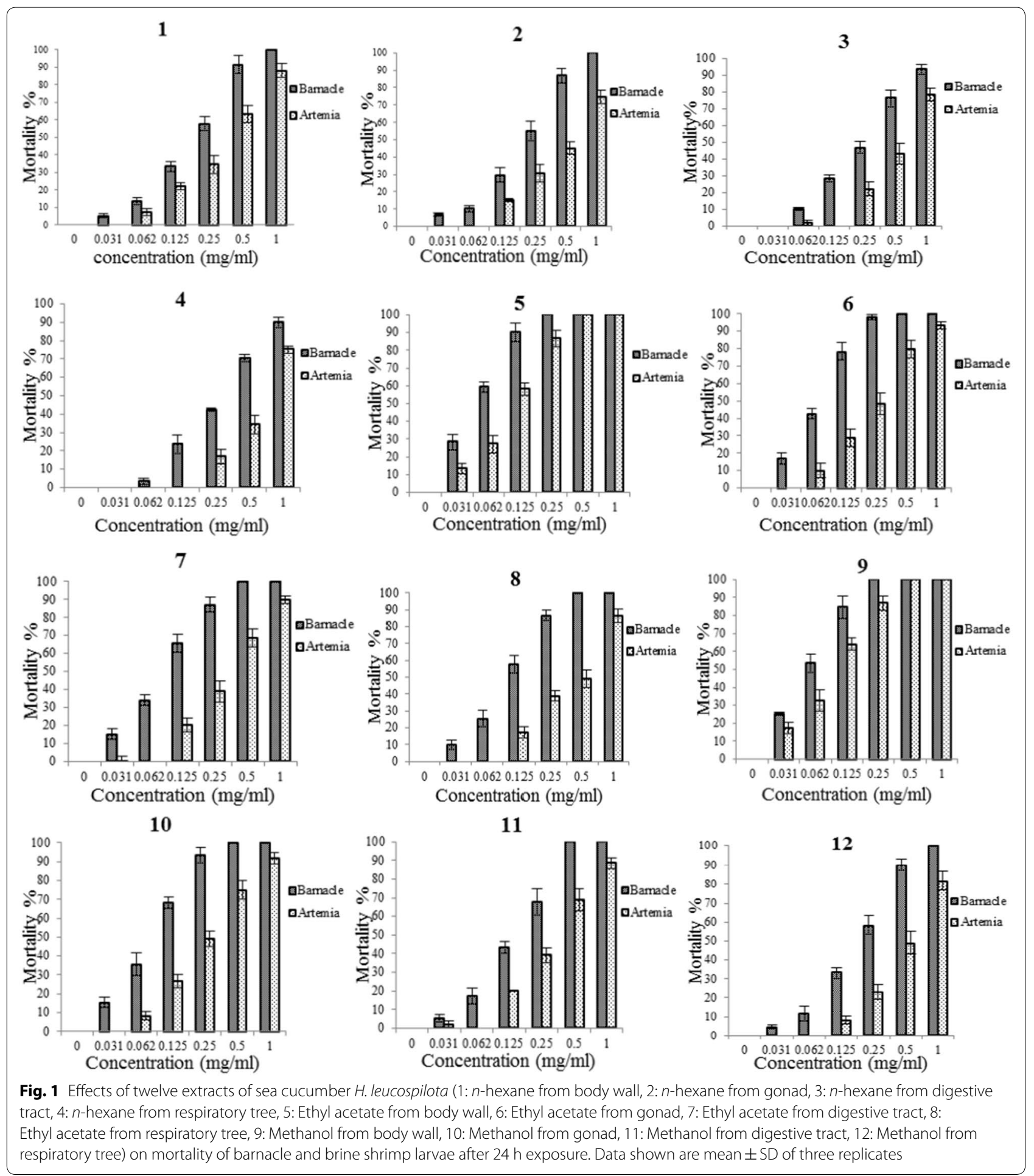

with the ethyl acetate extract indicating that it is a proper solvent to extract the bioactive compounds with antibacterial and antifouling activity from $H$. leucospilota. This suggests that antifouling and antibacterial compounds from $H$. leucispilota organs are mostly semi polar. This is further discussed by the results of GC/MS analysis.

Among the tested bacteria, K. pneumoniae and $S$. aureus were noted as the most resistant and sensitive bacteria, respectively. Mashjoor et al. [47] also reported 


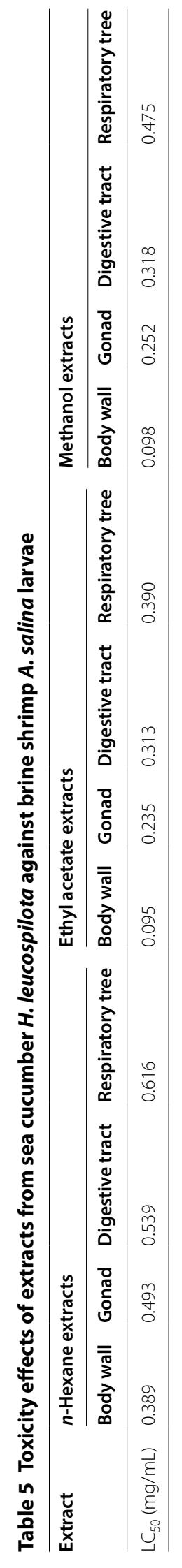


Table 6 The major components detected in the ethyl acetate extract from the body wall of sea cucumber $\mathrm{H}$. leucospilota

\begin{tabular}{|c|c|c|c|}
\hline Category & Compounds & Retention time & Aria $\%$ \\
\hline \multirow{5}{*}{$\begin{array}{l}\text { Terpenes and Terpe- } \\
\text { noids }\end{array}$} & Olean-12-ene-3,28-diol, (3ß)- & 10.239 & 14.116 \\
\hline & Neoisolongifolene, 8-bromo & 10.893 & 5.992 \\
\hline & Lumisantonin & 11.071 & 6.130 \\
\hline & Cyclohexane, 1,1-bis(5-methyl-2-furyl)- & 11.749 & 8.225 \\
\hline & Phorbol & 12.244 & 6.228 \\
\hline \multirow[t]{6}{*}{ Fatty acids } & Oleic Acid & 14.68 & 4.753 \\
\hline & Palmitoleic acid & 17.929 & 2.065 \\
\hline & Arachidonic acid & 19.84 & 2.776 \\
\hline & cis-13-Eicosenoic acid & 19.941 & 4.281 \\
\hline & Eicosanoic acid & 20.9 & 1.560 \\
\hline & 22-Tricosenoic acid & 25.379 & 1.540 \\
\hline \multirow[t]{6}{*}{ Others } & Propanoic acid-3-oxo, 3-(2,4-dichlorophenyl)-, ethyl ester & 10.308 & 3.721 \\
\hline & Tetracyclo[6.1.0.0(2,4).0(5,7)]nonane, 3,3,6,6,9,9-hexaethyl-, cis,cis,trans- & 11.241 & 8.402 \\
\hline & 1-Heptatriacotanol & 12.434 & 5.035 \\
\hline & 1,4-Hexadien-3-one, 5-methyl-1-[2,6,6-trimethyl-2,4-cyclohexadien-1-yl]- & 12.907 & 4.114 \\
\hline & Hexadecanoic acid, 2-hydroxy-1-(hydroxymethyl)ethyl ester & 23.632 & 2.694 \\
\hline & 17-Pentatriacontene & 24.919 & 2.242 \\
\hline
\end{tabular}

that $K$. pneumoniae was one of the most resistant bacteria to marine macroalgae extracts.

The results of the present study showed that all the tested extracts inhibited diatom $C$. muelleri growth. The MIC of the ethyl acetate extract of the body wall was found to be $0.062 \mathrm{mg} / \mathrm{mL}$ against $C$. muelleri. In a study published in 2016 [6] Suresh et al. reported that three marine diatoms tested (P. elongatum, T. frauenfeldii and $N$. longa) showed high sensitivity to Padina tetrastromatica extract with a MIC of $0.001 \mathrm{mg} / \mathrm{mL}$. The results of the present study also showed that all of the twelve extracts had higher inhibitory activity against $C$. muelleri compared to $C$. vulgaris. The more resistance of $C$. vulgaris could be referred to its cellular structure [48].

In the present study, six extracts showed moderate anti-barnacle activity with $\mathrm{LC}_{50}$ values all below 0.1 and above $0.048 \mathrm{mg} / \mathrm{mL}$. Kitano et al. [42] described moderate anti-barnacle activity when $\mathrm{LC}_{50}$ values are below 0.07 and above $0.021 \mathrm{mg} / \mathrm{mL}$. On the other hand, among the twelve extracts, ten extracts showed very low toxicity against non-target organism $A$. salina. This is a very important ability for an environmental friendly antifouling candidate to have appropriate activity against target organisms like barnacle and low toxicity to non-target organisms like artemia.

Based on the antifouling activities against all the tested bacterial strains, diatoms, microalgae, barnacles and artemia, the ethyl acetate extract of body wall was selected for the GC/MS analysis. In the ethyl acetate extract from the body wall of $H$. leucospilota, the presence of fatty acids and terpenes were observed by the
GC/MS analysis. In line with the present study, many fatty acids, terpene and terpenoids from sea cucumbers have been reported to possess antibacterial, antifouling and cytotoxic activity [30,49-51]. The presence of fatty acids including Eiosadienoic, Oleic, Arachidonic, Heptadecanoic and Palmitoleic acids was reported previously in holothurian species as well [30]. Similarly, several studies have reported the presence of terpenes like triterpene glycosides in some species of sea cucumber [30, 52-54]. These bioactive compounds have been reported to possess antibacterial and cytotoxic activities.

We observed that the organic solvent-extractable compounds from the sea cucumber $H$. leucospilota might play role in antifouling activities. The present results revealed that the ethyl acetate extract especially from body wall of $H$. leucospilota, is promising as a candidate antifouling agent. The results may be applied in further studies on the development of eco-friendly antifouling coats.

\section{Acknowledgment \\ We are grateful to a number of assistants who helped in the sampling process. \\ Authors' contributions \\ This study was part of the Ph.D. of the first author, who collected the samples, conducted the analyses, interpreted the data and wrote the manuscript. MMS and MY supervised and advised the entire research work. They also carried-out all the fieldwork necessary and regularly reviewed the writing of this manuscript. IS assisted with the writing of the manuscript. MZ helped the first author during the research work and conducted the chemical analyses. All authors read and approved the final manuscript.}

\section{Funding}

This research was financially supported by University of Guilan. 


\section{Availability of data and materials}

The datasets used and/or analysed during the current study are available from the corresponding author on reasonable request.

\section{Ethics approval and consent to participate}

The authors followed the Ethical Responsibilities according to the Committee on Publication Ethics (COPE).

\section{Consent for publication}

Not applicable.

\section{Competing interests}

The authors declare that there is no competing interests.

\section{Author details}

${ }^{1}$ Department of Fisheries, Faculty of Natural Resources, University of Guilan, Sowmeh Sara, Iran. ${ }^{2}$ Department of Marine Biology, Faculty of Marine Science and Technology, University of Hormozgan, Bandar Abbas, Iran. ${ }^{3}$ Department of Fisheries, Faculty of Marine Science and Technology, University of Hormozgan, Bandar Abbas, Iran. ${ }^{4}$ Department Of Chemistry, Faculty of Basic Science, University Of Hormozgan, Bandar Abbas, Iran

Received: 19 March 2019 Accepted: 24 January 2020

Published online: 06 February 2020

\section{References}

1. Soliman YAA, Brahim AM, Moustafa AH, Hamed MAF. Antifouling evaluation of extracts from Red Sea soft corals against primary biofilm and biofouling. Asian Pac J Trop Biomed. 2017;7(11):991-7.

2. Moreira JMR, Teodósio JS, Silva FC, Simões M, Melo LF, Mergulhão FJ. Influence of flow rate variation on the development of Escherichia coli biofilms. Bioprocess Biosyst Eng. 2013:36(11):1787-96.

3. Xin X, Huang G, Zhou X, Sun W, Jin C, Jiang W, et al. Potential antifouling compounds with antidiatom adhesion activities from the sponge-associated bacteria, Bacillus pumilus. J Adhes Sci Technol. 2017;31(9):1028-43.

4. Gittens JE, Smith TJ, Suleiman R, Akid R. Current and emerging environmentally-friendly systems for fouling control in the marine environment. Biotechnol Adv. 2013:31(8):1738-53.

5. Nandakumar K, Yano T. Biofouling and its prevention: a comprehensive overview. Biocontrol Sci. 2003:8(4):133-44.

6. Suresh M, lyapparaj P, Anantharaman P. Antifouling activity of lipidic metabolites derived from Padina tetrastromatica. Appl Biochem Biotechnol. 2016;179(5):805-18.

7. Soliman YA, Ibrahim AM, Tadros HR, Abou-Taleb AE, Moustafa AH, Hamed MA. Antifouling and antibacterial activities of marine bioactive compounds extracted from some red sea cucumber. Int J Contemp Appl Sci. 2016;3(9):83-103.

8. Piola RF, Dafforn KA, Johnston EL. The influence of antifouling practices on marine invasions. Biofouling. 2009;25(7):633-44.

9. Schultz MP, Bendick JA, Holm ER, Hertel WM. Economic impact of biofouling on a naval surface ship. Biofouling. 2011:27(1):87-98.

10. Tarełko W. The effect of hull biofouling on parameters characterising ship propulsion system efficiency. Polish Marit Res. 2014:21(4):27-34.

11. Demirel YK, Uzun D, Zhang Y, Fang HC, Day AH, Turan O. Effect of barnacle fouling on ship resistance and powering. Biofouling. 2017:33(10):819-34.

12. IMO. Focus on IMO: Anti-fouling systems. International Maritime Organization. London; 2002. p. 1-31.

13. Mimura H, Sato R, Sasaki Y, Furuyama Y, Taniike A, Yoshida K, et al. Accelerator analysis of tributyltin adsorbed onto the surface of a tributyltin resistant marine Pseudoalteromonas sp. cell. Int J Mol Sci. 2008;9(10):1989-2002.

14. Iyapparaj $P$, Revathi $P$, Ramasubburayan R, Prakash $S$, Anantharaman $P$, Immanuel G, et al. Antifouling activity of the methanolic extract of Syringodium isoetifolium, and its toxicity relative to tributyltin on the ovarian development of brown mussel Perna indica. Ecotoxicol Environ Saf. 2013;89:231-8.
15. Qian P-Y, Xu Y, Fusetani N. Natural products as antifouling compounds: recent progress and future perspectives. Biofouling. 2010;26(2):223-34

16. Bellotti N, Deyá C, Del Amo B, Romagnoli R. Antifouling paints with zinc 'tannate'. Ind Eng Chem Res. 2010;49(7):3386-90.

17. Oikonomou EK, latridi Z, Moschakou M, Damigos P, Bokias G, Kallitsis JK. Development of $\mathrm{Cu}_{2+}$ - and/or phosphonium-based polymeric biocidal materials and their potential application in antifouling paints. Prog Org Coatings. 2012;75(3):190-9.

18. Pérez M, Blustein G, García M, del Amo B, Stupak M. Cupric tannate: a low copper content antifouling pigment. Prog Org Coatings. 2006;55(4):311-5.

19. Rajan R, Selvaraj M, Palraj S, Subramanian G. Studies on the anticorrosive \& antifouling properties of the Gracilaria edulis extract incorporated epoxy paint in the Gulf of Mannar Coast, Mandapam, India. Prog Org Coatings. 2016;90:448-54.

20. Fitridge I, Dempster T, Guenther J, de Nys R. The impact and control of biofouling in marine aquaculture: a review. Biofouling. 2012;28(7):649-69.

21. Thomas KV, Brooks S. The environmental fate and effects of antifouling paint biocides. Biofouling. 2010;26(1):73-88.

22. Chen S, Ma C, Zhang G. Biodegradable polymers for marine antibiofouling: poly( $\varepsilon$-caprolactone)/poly(butylene succinate) blend as controlled release system of organic antifoulant. Polym (United Kingdom). 2016;90:215-21.

23. Clare AS. Marine natural product antifoulants: status and potential. Biofouling. 1996;9(3):211-29.

24. Qian P-Y, Xu SY. Antifouling activity of marine natural products. In: Handbook of marine natural products. 2012. p. 749-821.

25. Acevedo MS, Puentes C, Carreño K, León JG, Stupak M, García M, et al. Antifouling paints based on marine natural products from Colombian Caribbean. Int Biodeterior Biodegrad. 2013;83:97-104.

26. Sipkema D, Franssen MCR, Osinga R, Tramper J, Wijffels RH. Marine sponges as pharmacy. Mar Biotechnol. 2005;7(3):142-62.

27. Bordbar S, Anwar F, Saari N. High-value components and bioactives from sea cucumbers for functional foods - a review. Mar Drugs. 2011:9(10):1761-805.

28. Pangestuti $R$, Arifin Z. Medicinal and health benefit effects of functional sea cucumbers. J Tradit Complement Med. 2018;8(3):341-51.

29. Bondoc KGV, Lee H, Cruz LJ, Lebrilla CB, Juinio-Meñez MA. Chemical fingerprinting and phylogenetic mapping of saponin congeners from three tropical holothurian sea cucumbers. Comp Biochem Physiol. 2013;166(3-4):182-93.

30. Mert Ozupek N, Cavas L. Triterpene glycosides associated antifouling activity from Holothuria tubulosa and H. polii. Reg Stud Mar Sci. 2017:13:32-41.

31. Datta D, Nath Talapatra S, Swarnakar S. Bioactive compounds from marine invertebrates for potential medicines - an overview. Int Lett Nat Sci. 2015;34:42-61.

32. Janakiram N, Mohammed A, Rao C. Sea cucumbers metabolites as potent anti-cancer agents. Mar Drugs. 2015;13:2909-23.

33. Han H, Yi YH, Li L, Liu BS, La MP, Zhang HW. Antifungal active triterpene glycosides from sea cucumber Holothuria scabra. Acta Pharm Sin. 2009;44(6):620-4

34. Tian $F$, Zhang $X$, Tong $Y, Y i$, Z Zhang $S$, Li L, et al. PE, a new sulfated saponin from sea cucumber, exhibits anti-angiogenic and anti-tumor activities in vitro and in vivo. Cancer Biol Ther. 2005:4(8):874-82.

35. Althunibat OY, Hashim RB, Taher M, Daud JM, Ikeda MA, Zali B. In vitro antioxidant and antiproliferative activities of three malaysian sea cucumber species. Eur J Sci Res. 2009;37(3):376-87.

36. Majid A, Maryam E, Reza DA, Neda S, Ghodrat M. New observation of two sea cucumber species from Abu Musa Island (Persian Gulf, Iran). Eur J Exp Biol. 2012;3(2):611-5.

37. Mamelona J, Pelletier É, Girard-Lalancette K, Legault J, Karboune S, Kermasha S. Quantification of phenolic contents and antioxidant capacity of Atlantic sea cucumber. Cucumaria frondosa. Food Chem. 2007;104(3):1040-7

38. Vanden Berghe DA, Vlietinck AJ. Screening methods for antibacterial and antiviral agents from higher plants. In: Dey P, Harbone J, editors. Methods in Plant Biochemistry. London: Academic Press; 1991. p. 47-69.

39. Guillard RRL. Culture of Phytoplankton for Feeding Marine Invertebrates. In: Culture of Marine Invertebrate Animals. 1975. p. 29-60. 
40. Feng DQ, Ke CH, Lu CY, Li SJ. Herbal plants as a promising source of natural antifoulants: evidence from barnacle settlement inhibition. Biofouling. 2009;25(3):181-90.

41. Venkatnarayanan S, Murthy PS, Kirubagaran R, Venugopalan VP. Effect of chlorination on barnacle larval stages: implications for biofouling control and environmental impact. Int Biodeterior Biodegrad. 2016;109:141-9.

42. Kitano Y, Akima C, Yoshimura E, Nogata Y. Anti-barnacle activity of novel simple alkyl isocyanides derived from citronellol. Biofouling. 2011;27(2):201-5.

43. Liu H, Chen SY, Guo JY, Su P, Qiu YK, Ke CH, et al. Effective natural antifouling compounds from the plant Nerium oleander and testing. Int Biodeterior Biodegrad. 2018;127:170-7.

44. Gohari AR, Hadjiakhoondi A, Sadat-Ebrahimi SE, Saeidnia S, Shafiee A. Cytotoxic terpenoids from Satureja macrantha C A Mey. Daru. 2005;13(4):177-81.

45. Baron E, Finegold S. Methods for testing anti-microbial effectiveness. In: Stephanie M, editor. Diagnostic microbiology. Baltimore: Mosboy; 1990. p. 171-94.

46. Farjami B, Nematollahi MA, Moradi Y, Irajian G, Nazemi M, Ardebili A, et al. Antibacterial activity of the sea cucumber Holothuria leucospilota. Int J Mol Clin Microbiol. 2013;3(1):225-30.

47. Mashjoor S, Yousefzadi M, Esmaeili MA, Rafiee R. Cytotoxicity and antimicrobial activity of marine macro algae (Dictyotaceae and Ulvaceae) from the Persian Gulf. Cytotechnology. 2016;68(5):1717-26.

48. Safi C, Zebib B, Merah O, Pontalier PY, Vaca-Garcia C. Morphology, composition, production, processing and applications of Chlorella vulgaris: a review. Renew Sustain Energy Rev. 2014;35:265-78.
49. Zhang SY, Yi YH, Tang HF. Bioactive triterpene glycosides from the sea cucumber Holothuria fuscocinerea. J Nat Prod. 2006;69(10):1492-5.

50. Zou Z, Yi Y, Wu H, Yao X, Du L, Jiuhong W, et al. Intercedensides D-I, cytotoxic triterpene glycosides from the sea cucumber Mensamaria intercedens lampert. J Nat Prod. 2005;68(4):540-6.

51. Drazen JC, Phleger CF, Guest MA, Nichols PD. Lipid, sterols and fatty acid composition of abyssal holothurians and ophiuroids from the NorthEast Pacific Ocean: food web implications. Comp Biochem Physiol. 2008;151(1):79-87.

52. Wang Z, Gong W, Sun G, Tang H, Liu B, Li L, et al. New holostan-type triterpene glycosides from the sea cucumber Apostichopus japonicus. Nat Prod Commun. 2012;7(11):1431-4.

53. Han H, Zhang W, Yi YH, Liu BS, Pan MX, Wang XH. A novel sulfated holostane glycoside from sea cucumber Holothuria leucospilota. Chem Biodivers. 2010;7(7):1764-9.

54. Kalinin VI, Aminin DL, Avilov SA, Silchenko AS, Stonik VA. Triterpene glycosides from sea cucucmbers (holothurioidea, echinodermata) Biological activities and functions. Stud Nat Prod Chem. 2008;35:135-96.

\section{Publisher's Note}

Springer Nature remains neutral with regard to jurisdictional claims in published maps and institutional affiliations. 